\title{
CHARACTERISTICS OF TRADITIONAL VIETNAMESE FAMILY AND ITS INFLUENCE ON COMMUNICATION CULTURE IN THE FAMILY
}

DOI: http://doi.org/10.26758/11.1.4

Thi Kim Dung LE

Faculty of Sociology and Social work, Hue University of Sciences, Vietnam; $\mathrm{PhD}$ student at Faculty of Sociology and Social work, Bucharest University, Romania

Address correspondence to: Thi Kim Dung Le, Faculty of Sociology and Social work, Hue University of Sciences, 77 Nguyen Hue Street, Hue city, Vietnam; Ph.: +84987424920; E-mail: kimdungkls@gmail.com

\begin{abstract}
Objectives. Understanding the family's communication culture means understanding the ethnic communication culture, therefore, research on communication culture in the family has an important and practical meaning. The article aims to study generalize the basic characteristics of Vietnamese traditional families, thereby understanding the communication culture in the family, which is the basis for understanding the traditional communication culture of Vietnamese people.

Material and methods. This research is done based on the synthesis and analysis of documents related to family and communication in family to make comparisons and make appropriate judgments. 58 scientific value and reliable documents are searched on online databases, websites, indexes and printed documents, typed files in the computer, and then classified by topic groups for analysis. The documents mentioned or cited in the article are fully shown in the list of references.

Results. The traditional Vietnamese family has the characteristics of the traditional Asian family; this family model that has dominated all the values and standards of the family, which has a profound effect on the communication culture in the family. It is a type of communication that follows hierarchical order and pattern from top to bottom, emphasis on factors of location, age, gender and communication space.

Conclusions. Communication culture in the traditional Vietnamese family bears the imprint of wet rice civilization as well as Confucian and Buddhist ideology creating a polite, flexible communication style and cultural behavior, order and discipline in the family; however, its limitation is hesitation, inhibits personal criticism; there are stricter stereotypes against some family members. Currently, some of the traditional Vietnamese family's foundations have been changed but the communication culture in the family still needs to be preserved to preserve the communication culture of the nation.
\end{abstract}

Keywords: communication, culture, communication culture, communication in the family, traditional Vietnamese family.

\section{Introduction}

Communication is a daily activity of people from birth to death. The family is the first environment in which people perform communication, through communication between members, the family performs the socialization function, helping each individual shape personality and integrate into life society. Therefore, communication becomes a regular and essential activity for exchanging information and transmitting culture from generation to generation, from individual to individual. Understanding how people communicate means understanding the cultural identity of a certain nation. Understanding the communication culture of a nation represents understanding the origin and 
root culture of that nation. Therefore, communication and communication culture are interesting topics, attracting the research interests of many authors in the world as well as in Vietnam. Communication topic has been studied in many studies from the 50s and 60s of 20th century to clarify the meaning of communication concept (Stevens, 1950; Schachter, 1951; Hoben, 1954; Ayer, 1955; Alex, 1959; Barnlund, 1962; Cartier \& Hanvood, 1953; Miller, 1966; Andersen \& Guerrero, 1997; Ting-Toomey, 2018), then the concepts of communication was analyzed quite fully in the study of Dance (1970) and Luhmann (1992). However, it must be admitted this is too broad a concept and researchers often delve into smaller or specific aspects of communication, for example research on family communication.

Research on family communication is also a topic of interest to many authors and mainly focuses on interpersonal communication in the family (Robinson \& Levy, 1986; Beebe, Bebee, \& Redmond, 2000; Guerrero, Andersen, \& Afifi, 2007; Trenholm, 2008; DeVito, 2019). Studies of interpersonal communication in the family focus on the models and theoretical frameworks that characterize the communication occurring in the family, the role of family communication and the influence of the family communication environment to the ability to communicate of individuals (Moore \& Moschis, 1981; Barnes \& Olson, 1985; Moschis, Prahasto, \& Mitchell, 1986; Carlson \& Grossbart, 1988; Fitzpatrick \& Ritchie, 1994; Forehand et al., 1997; Koesten \& Anderson, 2004; Punyanunt-Carter, 2008; Schrodt et al., 2009). Through these studies, the issues of subjects, roles and tools of measuring family communication are also addressed and clarified. The studies have shown that family communication can be described as a combination of family members to balance and control information and relationship goals. Family communication takes place in a home environment. "The family communication environment is a set of norms governing the trade off between information and relational objectives of communication" (Fitzpatrick \& Ritchie, 1994, p. 524).

In Vietnam, family communication culture haved shown in many studies (Bùi, 1990, 1993, 1994; Đỗ, 1990; Nguyễn, 1993; Ngô, 2006; Phạm, 2012; Trương \& Trần, 2012; Khuất, 2014; Lê, 2015; Nguyễn, 2015; Bùi, 2018; Nguyễn, 2018). Meanwhile, traditional family culture is mentioned in many general studies on Vietnamese culture by some great scholars such as Trần (2001), Trần (1996, 1997, 1998, 2016), Trần (2005), Huỳnh (2012), Đào (2014). The studies of culture communication and communication in Vietnamese families have focused on cultural aspects traditional Vietnamese communication on the use of vocation, communication skills, attitudes in communication and the position between the speaker and the listener in communication. Thus, a general study on traditional communication culture in Vietnamese families is almost not mentioned, this became an inspiration for this research. The study aims to condense the basic characteristics in the traditional communication culture of the Vietnamese families, from which each individual, family has a sense of promoting good values, improving outdated elements, concomitant sharing a typical communication culture of Vietnamese families around the world.

\section{Material and methods}

This article explores the basic characteristics of the traditional Vietnamese family, then learn the communication culture in the traditional family, so the mainly materials of research based on secondary sources. In order to identify, locate and create a secondary database for the research topic, researcher conducted a search of publications by keywords (communication, culture, communication culture, communication in the family, traditional Vietnamese family) in professional journals. There are a total of 58 well-searches online databases and indexes, focusing mainly on "Google scholar", "Research gate", "Jstor" with many other trusted websites and libraries (such as libraries of universities, website of Ministry of culture - sport and tourism, local website etc.) and printed documents, typed files in the computer to collect the most appropriate secondary source. After the documents were collected, the researcher divided into groups of topics to analyzed and cited. The 
documents on the same topic are also compared and collated to have a basis for making appropriate and relevant judgments, ensure the science and reliability of the research.

\section{Results}

\section{Traditional Vietnamese family characteristics}

Family is a concept that is approached under many different angles. From a sociological perspective, Giddens (2006) introduced the concept of "a family is a group of persons directly linked by kin connections, the adult members of which assume responsibility for caring for children" (p. 206). According to Psychological Dictionary, author Vũ (2008) introduces the concept "the family is the community of people living together under one roof, forming the smallest unit of society (also known as social cells) bound together by marriage and blood"; "the family is a miniature society consisting of one or more different generations living and working together in an organized, principled or unwritten way. Peace is ensured by warmth, a sense of security and love". From a legal perspective, "a family is a set of people bound together by marriage, blood relations or nurturing relations, giving rise to obligations and rights between them" (Quốc hội Việt Nam, 2000). From a cultural perspective, "family is a form of blood-relationship community - the earliest kind of human gathering and association; forming specific cultural forms that the ancient Vietnamese called "gia phong". "Gia phong" was understood as the lifestyle, habits, customs and manners of family members to organize the family, educate people, especially spiritually. Each family in different regions has its own nuances of family-style, which have its own characteristics of family organization, relationships and behavioral standards, and educational methods (Ngô, 2006, p. 26). From the above connotations, family is an overall widespread with biological, economic, social and cultural characteristics. Therefore, when caring about the family in terms of culture and family, it cannot be separated from its social and economic characteristics (Ngô, 2006, p. 27).

In general, the Vietnamese traditional family has many similarities with the common characteristics of traditional families Asian but also has unique characteristics. The traditional Vietnamese family has the characteristics of the traditional Asian family, always retaining the traditional nuances even when the society has reached a high level of industrial civilization, this is different from families in Western societies (Đỗ, 1990, p. 9). It is a family type characterized by an agricultural economy growing wet rice - Asian production method and village organization as a base (Lê, 2015, p. 20). However, the traditional concept also has many meanings, and in each different approach, one can only share a few of them. In the most common sense, the traditional family is the rural family, so the characteristic of Asian agrarian society is an important foundation for maintaining the long-standing and almost immutable family type on many sides. However, there also exists another way of understanding the concept of the traditional family, that is the type of family where the characteristic values of the spirit, morality, culture and religion are always appreciated and become a framework that defines standards and behaviors in the family. In this sense, the concept of traditional family in Vietnam is often used almost identical with the concept of "Confucian family". Thus, "people look for attributes of the traditional family in the influences of Confucian ideology that encompass a long history in Asian societies from China, Japan, Korea and whole of Vietnam" (Đỗ, 1990, p. 9). Reality has proven that, the search for the true social logic of the East Asian family with Confucian logic is a mistake. Although in China, Japan or Vietnam, the traditional family is all influenced by Confucianism, equally stable and strict in nature, the differences can still be found basic.

The traditional Chinese family carries the institution of "tu thân, tề gia, trị quốc, bình thiên hạ" (means that a gentleman must first train himself well, then arrange a good family, then rule the country and reassure the people) is the basic morality of gentleman to set the model of a family-like organization with the dominant position from village to country. Accordingly, the name of a family 
line has taken as the name of the village is popular. Yanfen cited by Đỗ (1990) mentioned "traditional Chinese family is a large collection of many members living, it includes not only direct descendants but also relatives, creating a family of three or four generations call tam đại đồng đưòng, tú đại đồng dưòng" (a three-generation family, a four-generation family also living under one roof), not just the present nuclear family (p. 10). Meanwhile, Kurimolo Kazuo cited by Đỗ (1990) argued the traditional Japanese IE family is seen as a social-economic institution rather than a community of bloodline (p. 10). Consequently, Confucian morality was originally directed towards political purposes in China, here it was directed towards economic goals (Đố, 1990, p. 10). Although it is also influenced by Confucian ideology, the traditional Vietnamese family does not have the characteristics of a sociopolitical institution, which is a huge difference from the Chinese family. The Vietnamese family is dependent and dominated by the village, the village unit is the foundation of the monarchy of Vietnam, not the family unit.

In Vietnam, the characteristics of the economy create the cultural characteristics of the family and community. $80 \%$ of Vietnamese people in the traditional society choose and associate with the economic sector mainly in agriculture, the agricultural life in rural areas is linked to families with villages. The pace of life of each individual and family revolves around symbols of banyan tree, river wharf, communal courtyard, bamboo rampart - community and autonomy of traditional Vietnamese village also formed from there. Although the agricultural life is worrisome and busy with crops, the village's festival activities are still the focal point attracting the participation of everyone in a relaxed and connected mind. That is also the basic root that shapes cultural values in the spiritual life of the people. In that context, community and autonomy are two aspects that seem to be contradictory but exist in parallel in all Vietnamese villages. Banyan tree, river wharf, communal courtyard are symbols of community. It creates the morality of family and society in Vietnam, upholding the spirit of solidarity, mutual reciprocity on the common order, on the interests of the family and collectively, on covenants, on sacrifice, on peace and taking family as the most important. The bamboo rampart is a symbol of autonomy, so many conventions and conventions that frame the individual and family in the village's customary are such that "custom rules the law". Autonomy encourages a spirit of hard work, independence and self-reliance, and it is fundamental to maintaining a self-sufficient agricultural economy that has existed for centuries. Each traditional Vietnamese family is considered as an agricultural production unit, due to its inclination to self-sufficiency, and agricultural production activities that help each family satisfy the living needs of its members.

The traditional families in Vietnam take the form of a semi-nuclearized family as the basis (Đỗ, 1990), so in terms of structure it can be divided into two main types of families: small family (one or one generation) and large family (extended family of three generations or more). The big family also follows the model of a three-generation family, a four-generation family also living under one roof, when the children are mature and married, parents often live with the family of their eldest son, other members of the family will live separately. In some families, due to economic conditions, there are still many couples, kids and grandchildren living in the same house with their parents, but basically still parents living with the eldest son. This is not required by law, but it is by default in all Vietnamese villages. The most profoundly unifying element of traditional extended family is ancestor worship, followed by sharing other big family events (wedding, birth, new house) and economic aspects (supporting workers in the crop). Ancestor worship is performed in the family of the eldest son, an event with ritual worshiping can take place within the family or the whole lineages. From the characteristics of the lineages in Vietnam, it is appropriate to propose the concept of the lineage is understood as the kind of family extending according to the blood relation, the strength of a lineage is often expressed in aspects such as the success of the descendants and solidarity in the spirit of emotional attachment as well as mutual assistance. Each family has a genealogy, which is a treasure, although it does not have much meaning about the organization of life, but genealogy is the basis for establishing and maintaining order and hierarchy in the lineages. Genealogy has a special meaning in confirming whether a marriage relationship is allowed or not, because according to customary, in the 
lineages, marriage is strictly prohibited within a fifth generation relationship. The customary of relationships and behavior in the family, lineages are the implicit verbal defaults that didn't be expressed in writing. Although this customary is different in each locality or ethnic group (in Vietnam), basically all Vietnamese people know, understand and obey under the influence of the lineages.

The delineation of the position and hierarchy in the Vietnamese family is influenced by the characteristics of the wet rice agricultural economy (Đỗ, 1990) and Confucianism, with the ideology of promoting the role of men "nhất nam viết hữu, thập nữ viết vô" (having 1 son in a family means having kid, but even having 10 girls is still considered to have no kid) and there are many strict requirements for women such as "công dung ngôn hạnh", "tam tòng tứ đức". "Công dung ngôn hạnh" mentions four basic women's standards: "công" means to be good at housework, good at taking care of family; "dung" is formal beauty, appearance: loveliness, discreet, graceful; "ngôn" is a courteous, discreet, small, easy-to-hear speech associated with a well-mannered gesture that shows modesty; "hạnh" referring to morality, kindness, faithfulness and devotion, rich in love, keeping full familystyle. "Tam tòng tứ đức" means when a woman is at home, she has to listen to her father, until she gets married must listen to her husband, and when her husband dies, must listen to her son. In the family, to promote the role of men and to be strict with women so the upper and lower relationships are clear: father - kid; older brother - younger brother; husband - wife. These relationships are adjusted by the morality of "tam cương" (talk about three main relationships in society: king - citizen, father kid, wife - husband) and "ngũ thường" (refers to five ethics that a person should have and should have: personality, polite, righteousness, intellect, reputation). The husband is the mainstay and is usually the one who holds the name of all assets in the family, the wife has a lower status but has a huge role in money management, revenue and expenditure - the woman is considered the person who holds the hand of the key box, and manages the money in the family. Therefore, even though it is patriarchal family, the wife is truly the ruler (Đỗ, 1990). This is explained that in Vietnamese villages, besides Confucianism, there is another religion that is popular and has a great influence on the spiritual life of the people, which is Buddhism. Buddhism has been regarded as the religion of women and children for centuries, so it is the Buddhist teachings that soften Confucian notions of woman (Đỗ, 1990, p. 10).

The above is the basis for looking for a specific sociological approach to analyzing traditional Asian families in general and traditional Vietnamese families in particular. One thing has to admit that, all values and standards of the family are governed by that traditional family pattern. Therefore, in order to understand the traditional communication culture in a Vietnamese family, first of all, it is necessary to understand the characteristics of Vietnamese traditional families. Understanding this is also the basis for determining the changes of the traditional communication culture in the current Vietnamese family and the decisive factors for that change.

\section{Communication culture in traditional Vietnamese family}

Culture is a multifaceted concept, so there are many different definitions of culture. Parsonian cited by Lamont \& Small (2008) mentions culture as unitary and internally coherent set of attributes that characterizes a social group (p. 79). On the other hand, Ortner (1984) refers culture as what people produce and act on their environment. Fiske (2002) considers culture as "a set of customs, capacities, ideas, values, rules, institutions; cultural products created by society and passed down from generation to generation". It can be seen that the common point reflected in the connotation of most concepts of culture is the symbolic culture of the community. People create culture and on their side culture carries the mark of people in it.

The concept of communication is clarified in many respects in studies from the mid-20th century, that communication is related to: interaction/ relationship; reduction of uncertainty; process; transfer; linking; commonality; channel/ means; replicating memories; response/ change; stimuli; 
intentional; time/ situation; power. As such, the definitions of communication reflect all levels of fields from all meaningful behavior and purpose of people in conscious interaction (Dance, 1970). Thereby, it can be understood that communication is a process of transmitting information in a conscious way of people through symbols and words. Communication is an important activity that creates cultural values. In the family, communication plays an extremely important role, is a fundamental activity in family relationships, creating the culture of the family. Talking about culture refers to the symbols of a certain community, so the traditional culture of communication in a Vietnamese family is typical values of Vietnamese families in the context of Vietnamese community and society. On the basis of the wet rice agricultural economy, the Vietnamese people are intimately attached to nature and the universe, living in a peaceful, flexible, emotional, discreet, delicate, all forming principles and how to communicate and behave in Vietnam (Trần, 2001).

\section{Communication follows hierarchy}

Traditional communication culture in families is formed and maintained in the context of traditional Vietnamese families, and becomes an important part of family culture. The family is not only a specific social group, but also a biological - cultural entity, a social - cultural institution. Family from the beginning is a cultural existence, a cultural entity in close relation with biological factors and gender (Lê, 2015). Therefore, the communication culture in the family is shaped and standardized from the common standards of the family culture. In the traditional Vietnamese family, there are three values and standards that are appreciated, creating the family culture, including: "gia đạo", "gia phong" and "gia lế". "Gia đạo" is the moral standards that the family values, among those standards, filial is the highest value (filial piety to parents, ancestors). "Gia lễ" are customs in a family that are expressed through the way of eating, behaving, and walking that have been passed down through generations become a tradition and descendants must follow as a ritual hierarchy. "Lễ", according to Asian, not only means autonomy but also means human. In a word, then "all the treatment of the Asian people are in one word Lêิ" (Phạm, 2012). Many Vietnamese families in the past, thanks to their ability to maintain cultural behaviors, have created an order and discipline for everyone to follow. "Gia đạo", "gia phong" and "gia lễ" are the root of the family, keeping the people of Vietnam, the family and Vietnamese society a strong vitality and purity with their roots. "Gia đạo", "gia phong" and "gia lễ" are three important standards that govern and regulate family relationships and govern the behavior of family members not only towards the survivors but also towards the ancestors have passed away. All elements of family communication are referenced in the common standard of that family culture. Accordingly, the speaker, the listener, the communication content, the way of communication, the way of responding and the context of communication are all placed in the common cultural framework of the family. This cultural framework forms the principle of highly hierarchical communication and obey the hierarchy.

Principle of highly hierarchical communication guides the communicator in his or her role and position with the communicator and the context of communication. In terms of hierarchy in family communication, communicators must be aware of who they are in that communication relationship to have an appropriate way of communicating (vocative, attitudes, gestures). In the traditional communication of the Vietnamese family, the speaker usually targets the listener with two attitudes: polite or impolite expressed in four types of vocative nuances: (1) formal; (2) neutralization; (3) friendly, flippant; (4) buggery, contemptuous (Nguyễn, 1993). In a normal conversation, the speaker who in a high position (great grandparent, grandparents, parents, uncles, aunts) talking to their children or grandchildren can display one of three nuances of the address: (1) normal; (2) neutralization; (3) friendly, flippant. However, if the speaker in low position (kid, grandchildren) who talks to their great grandparent, grandparents, parents, aunts and uncles, they are only allowed to use the expression (1) formal. The principles of family vocation are often strict and very respectful, both according to the order of bloodline, and according to the age order, but the order of blood is still the 
decisive factor. Therefore, in the groups of vocative nouns, kinship nouns are used more often to ensure the exact position and hierarchy of the family members when communicating. If in English only "I" and "you" refer to the speaker and the listener, in Vietnamese, there are 3 ways of addressing people at lower position when talking to people at higher position, including: "con" (kid), "cháu" (grandchildren) and "em" (younger sister/ younger brother), the people at higher position depending on their position to responded. Specifically, speaker call "con" when talking to "bố" (father) and "mẹ" (mother); call "cháu"' when talking to "cụ" (great grandparent), "ông" (grandfather), "bà" (grandmother), "cô" (father's sister), "bác" (father's brother, mother's brother); "chú" (uncle); "dì" (mother's sister); "cậu" (mother's brother), "thím" (uncle's wife), "mợ" (wife of mother's brother), "dượng" (aunt's husband); call "em" (younger brother/ younger sister) when talk to "anh" (older brother) or "chị" (older sister). All vocative nouns that do not correspond exactly have their own meanings with different psychosocial colors: grandparents call their grandchildren is "con", parents call their children is "em" to show their intimacy affection between family members or an older person vocative to the younger being "mày" (you), "tao" (I) to expresses plain, intimate or maybe angry. Conversely, when a person in lower position vocative "tao" and call "mày" to a person in a high position, it will be attributed to chaotic and filial behavior. In different communication situations, a given word can reveal many different expressions, even opposites. For example, the vocation "ông" represents the normal relationship between a grandfather to his grandchild (or any elderly man when communicating with a young subject but does not have any blood relationship), but there are also cases where younger people vocative "ông" to an elderly, when a young man is in a quarrel with an older person, he says: "ông" (I) challenged "mày" (you) do that. In addition to the right vocative, there still exists the phenomenon of "vocation for replacement", which means that the vocation of the person who claims is not showing his position but in the position of others. For example, a kid calls his parents is grandparents when that kid also has a child. The way of vocation "grandparents" in this case mean that the parents call to replace their children. In Confucian culture, there is always the thought that men despise women, so they often use words for men first, words for women put behind in a phrase used by both sexes, such as "ông bà" (grandfather grandmother), "anh chị" (brother sister), "chú dì" (uncle aunt). The choice of forms of vocation clearly shows the position and power in the family as well as the attitude of the characters in communication. Therefore, the home network is a sustainable structure in which vocation have important role for showing attitudes, feelings. All forms of vocation in society are influenced by the choice of the form of vocation in the home network (Bùi, 2018).

The vocative communication mechanism is understood as a structured system of the vocative communication elements operating under a certain organization, including: vocative communication units (vocative words, structures and vocative pattern), speaker - the person called and the principles of vocative communication (Nguyễn, 1993). In the Vietnamese family, when the communication takes place, the speaker - the listener who wants to perform a proper vocative communication must determine how he and the object communicates in the relationship, especially save pay attention to factors of age, gender, position, and intimacy level. In terms of age, the older person must be called with respect, the position of the person of lower position shows respect for the person of high position, if the relationship is a close one, the vocation is also more intimate. This principle forms an implicit rule, when naming children, it is certain to avoid the same name as the superiors in the family. In terms of gender, Vietnamese language is very rich with the system of anonymous words to call in communication such as: "nàng", "thiếp", "người", "ngài", "mình", "ta" to use instead the name of husband - wife in the family ("nàng": the husband calls his wife, "thiếp": the wife calls herself; "chàng", "ngài", "người": wife calls her husband; "ta": used for both husband and wife when talking to the other; "mình": wife or husband calls the other). In addition to the above factors of age, gender, status, participants must pay attention to specific communication situations in terms of space, time, and purpose. 
Paying attention to communication space demonstrates the characteristic that values communication context. The traditional Vietnamese family communication space is usually the space during a meal or after a meal when all family members enjoy tea and chat. Communication space is sometimes extended in the workplace (in the garden, in the field, for example, people weeding, transplanting rice, digging peanuts, etc. and talking together). Communication contexts can show a state of close, intimate connection, but can also be formal, serious, and even heavy. Conversations around the tray are often associated with problems or daily activities of the family, so the main theme is temperate and intimate. One of the unique culinary cultural traits of Vietnamese people is the sense of community shown right on the tray: food is share and everyone eats together, including a bowl of sauce. That has a lot to do with the way Vietnamese people eat and communicate when they eat. People of high position, the elderly take the food first and then the people of low position, children must invite the adults before eating. Therefore, in the Vietnamese food culture, there is a saying "be careful of possible faux pas", this regulates the behavior of family members when eating together. Everyone has just eaten but must also listen and observe to ensure dignity and show respect for the superior, the elderly. Children in the family are also taught how to eat slowly and especially when chewing, they don't talk. The context of family communication is sometimes extended in family meetings, which often have different emotional nuances depending on the content and purpose of the meeting. If it is a family meeting about rejoicing (getting married, building a house, reaping crops), the emotional state is usually comfortable and happy. However, if it is a meeting that involves dealing with unusual incidents in the lineages, for example descendants in the offending family line (theft, unmarried daughter pregnant) then the atmosphere is heavy. Most family meetings involve the elderly, so when young people want to consult and exchange information, they must be allowed and use honorifics with the people have higher position when speaking.

Communication context in traditional Vietnamese families is often associated with communication time. Communication time is usually while the family is eating and working, but perhaps the main time is still the evening when everyone is drinking tea and talking. Because this is the time when most of the family's day-to-day tasks have been settled, everyone is in an accommodating and relaxed mood while enjoying tea and chatting. Stories on the teapot or tray are often related to family, how to organize life, assign tasks for tomorrow, ask questions, remind children's education, but can also be stories about village communities. Later, when economic conditions as well as technology developed, family members drank tea, watched television and discussed together. There, although technology has begun to take part in family life, almost every family member shares activities together with content on television: watching news, watching movies, listening to music and entertainment together. Although there are intermediaries involved, the communication of family members is still guaranteed.

Thus, all factors of age, gender, role, context, time or family communication purpose create a multi-dimensional space, helping to realize communication and vocative behavior in communication of Vietnamese family. Understand that multidimensional space in vocation and family communication is to grasp the key of the traditional communication and help each family member perform appropriate and effective communication behavior.

\section{Communication emphasizes top-down pattern}

Communication follows the principles of promoting hierarchies, so sharing and communicating information is usually one-way from top to bottom. Listening, receiving and responding to information in communications of low position people often must comply with standards in eye contact, attitudes expressed through verbal and nonverbal language. Therefore, in traditional Vietnamese family, parents attach great importance to teaching their kids "think today, speak tomorrow", "courtesy costs nothing", "the cobbler should stick to his last", "words must be weighed, not counted" it emphasizes that the speaker must be very careful before saying anything. 
When people are angry, do not say anything, because "word is silver but silence is gold". Even people at higher position like grandparents, parents must also pay attention to this to act as an example for younger people. On the contrary, those at lower position and younger people have to be more cautious when speaking so as not to make messy mistakes with those above, violating the family hierarchy. Vietnamese people say "cha mẹ đặt đâu con ngồi đó", it's mean kids must follow all parental, arrangements cover all the implications of parents' influence on their kids in the family, including life-long greatness such as (marriage) to daily routine (communication). That affirms parents' right to make decisions over all their kid's problems. Accordingly, imposing communication has also become common in many families, parents say what their kids must obey. Because, in traditional Vietnamese society, kids obey their parents is one of the criteria to show a good, filial and polite son. Gradually it shapes the habit of one-way communication, that is, kids, people at low position only receive information from adults and obey, less critical and objectionable. Judging from the point of view of the kids and people at low position is often seen as disobeying their parents - one thing to avoid in the family. The limitation from this communication feature is that the formation of generations is only obedient without their own opinion, so personal development is also inhibited.

In addition, the delicate, circular communication style that makes all family members, big or small, when expressing their opinions, is often less likely to open up directly to issues like in the West. Delicate and caring communication style is the product of a respectful lifestyle and a way of thinking that values relationships. This method of communication contributes to maintaining affection, harmony, joy, avoiding family conflicts and quarrels, but its disadvantage is its lack of assertiveness and frankness. Vietnamese people love harmony, so they always try to maintain solidarity and happiness in the family; each family member must be educated and trained to have appropriate communication. The ability to communicate, namely the kid's ability to speak and behave, is the appearances of their parents, parents pay much attention to this, so they often teach their kids how to communicate in a proper manner. The teaching content is not only the way of speaking, how to convey it, but also the tone of the communication.

Hierarchical communication is also reflected in the ritual in a very polite and rich way of speaking, the people at lower position always have to use honorifics when talking to the people at high position and the elderly. Right vocation shows the full educational environment that is received from children to adults and shows how that individual is in dealing with human beings. It requires the speaker and the listener to attach to different honorifics, and to state the subject and the predicate in which. Depending on the position of each person in the communication relationship, honorifics are also used with different degrees.

\section{Through communication to teach communication}

Admittedly, people begin to communicate from birth with early behaviors such as: eye contact, physical contact, conversation between adult and child. This has been made clear through the psychiatrist Bowlby's theory of attachment, who affirms that "attachment is a long-term psychological relationship between people" and that attachment begins at a young age newborn baby (Bowlby, 1969). The theory of attachment states that infants enjoy human company and that most infants respond equally to any caregiver when the child before the age of 6 months (McLeod, 2017).

In the Vietnamese family, in addition to the usual ways of communication such as conversation, body caressing, eye contact, the adults in the family have a special way of communicating with the child, which is "lullaby". Lullaby is performed with the purpose of helping the child to fall asleep easily, feel secure and warm when sleeping, but from this activity it creates a unique way of communication, that is how adults show love for children, and also a way of educating the child from birth. From there, forming a precious treasure of lullabies for which grandmother and mother are the main transmitters to the child, sometimes the men also perform this work. Through lullabies, adults comfort the child to go to sleep, but more importantly transmit the teachings, basic 
values, good manners, speech, in human morality. From that way of communication, the child will know filial piety with ancestral root, the merits of parents, the peaceful affection between brothers, and the behavior of words and voices to be human. The process of socialization of a child starts from those everyday actions, each child in the family is raised with a treasure of proverbs, singing performed through lullabies about how to be human. From the way family functions, it can be stated that the socialization function of the traditional Vietnamese family not only focuses on teaching children, directing them towards scientific knowledge, but first of all, towards human morality. That process continues every day, as the child grows up, the lullabies are replaced by moral and benevolent stories, to teach the child how to live and behave humanly, then the discussions about daily life. Every story, event has an educational implication in it. When a child is well educated there will be good manners and communication, because personal honour is tied to the ability to communicate, good words spoken leave marks, forming a reputation; bad words spread to many people's ears, creating disreputable. In addition, the respect of family dignity makes parents in traditional Vietnamese families aware of teaching their children to behave in an ethical manner, because in the community "bad news has wings". Children must be cultivated so as not to affect the honour of their parents, ancestors, because "the apple never falls far from the tree".

Thus, Vietnamese people attach special importance to communication and love to communicate; although they like to communicate, Vietnamese people have the opposite, almost, timid characteristic and be careful in communication. The coexistence of these two opposing personalities (like to communicate and shy) stems from two basic characteristics of Vietnamese villages: community and autonomy. Put this in the context of family communication, everyone in the family communicates very openly, but outside the family, it is quite timid, meeting strangers is even more quiet. Children, people lower position when communicating with adults must be cautious and cautious. These two seemingly contradictory personalities do not contradict each other, they are two sides of the same nature, a manifestation of the flexible behavior of the Vietnamese people.

\section{Discussions}

This research explores the basic characteristics of the traditional Vietnamese family pattern and the characteristics of the communication culture dominated by this family pattern. In synthesis, there are linked and analyzed relevant documents to discover those features. There are two main issues to clarify in this study, which are also more extensive and complete than previous studies on traditional Vietnamese family and family communication culture.

As in previous studies as Trần (2001), Trần (1996, 1997, 1998, 2016), Trần (2005), Huỳnh (2012), Đào (2014), the family pattern is shaped by the specific economic conditions and cultural and social contexts of the country. This is clearly reflected in the characteristics of Asian production methods - with the core base of the wet rice agricultural economy. However, on that common background, each Asian country also has its own ethnic characteristic and the Vietnamese family depends on and is dominated by villages. Village units are the foundation of the monarchy of Vietnam, not the family unit. Vietnamese village is the place where the community and autonomy is most clearly shown and in that particular context, the family culture, including the communication culture, has a clear mark. It should also be added that the community and autonomy in the village as well as the expression in the family are not two opposing and mutually exclusive states, on the contrary, these two characteristics are complementary to create high cohesion but still have differences and encourage autonomy and independence.

In addition to the economic context, ideology is also an important factor affecting the lifestyle and culture of the Vietnamese people and the Vietnamese family. Specifically, it is the Buddhist and Confucian ideology that creates strict rules, expressing hierarchy (Confucianism) but also very humane (Buddhism), thereby creating the model of family and obey the defence is in a family order, but also very soft and harmonious (Đỗ, 1990). Therefore, Vietnamese family's notion 
is only influenced by Confucianism creates harshness for some family members is not really satisfactory, because before Confucian introduction, Vietnam was an independent country, a culture with its own basic characteristics.

Communication culture in traditional Vietnamese family through this study shows the following: all elements of family communication are referenced in the common standards of family culture, forming principles communicate highly and hierarchically, communication emphasizes the principle of top-down stereotypes. It can be seen that the principle of communication upholding and obeying the hierarchy requires that participants to always pay attention to the hierarchy of communication relationships, but it seems very natural and is not basically a mode of communication that limits the communication level or ability of family members. This is actually easy to understand and explain, because what comes from the family and community culture, all members of that cultural context practice cultural norms freely natural and voluntary. Therefore, Vietnamese people have a way of transmitting the family culture, including a specific communication culture: through communication to teach communication.

Research results also show that although communication emphasizes top-down stereotypes according to the hierarchy is maintained in the social relations of the Vietnamese people (Nguyễn \& Cao, 2012), Vietnamese people also seek to soften it through opening and leading communication in a subtle, circular manner to increase the communicator's encouragement to participate in communication. According to the Confucian influence, the moral concept of "tam cương, ngũ thường" has quite profoundly influenced three core relationships in society: king - people, father child, wife - husband. Setting in the family context shows the clear shaping the father - child, wifehusband relationship through behavior and communication, in which the husband, the father has the biggest role and position in the family, has strongest influence on the remaining members. But it is also important to see that this father - child relationship has expanded further into a parent-child relationship. Therefore, in general, parents have a profound influence on their children, even on the communication aspect that creates the imposed communication from top to bottom. This communication limits the power and the capacity to criticize from low - position people (children) to high - position people (parents) in the family, it tends to the principle of listening and passive reception of the low - position people (children). To soften this principle, Vietnamese people build a habit of delicate and thoughtful communication, which is also a product of a dignified lifestyle and a way of thinking that values relationships. This way of communication contributes to maintaining affection, harmony, joy, and avoiding conflicts and quarrels in the family. Therefore, despite focusing on the way of communicating that is highly hierarchical and imposed from above, Vietnamese people still maintain a respectful, flexible communication style that has created a cultural behavior, creating a background order, discipline for everyone to follow.

\section{Conclusions}

Traditional culture of communication in the Vietnamese family was formed, preserved and developed for a long time, bearing the imprint of wet rice civilization as well as Confucian and Buddhist ideology. The respectful but flexible way of communication has created a cultural behavior, creating an order and discipline for everyone to follow. However, the limitation of this communication style is the lack of assertiveness, inhibiting personal criticism; the overestimation of the reputation and dignity of the family creates stricter stereotypes against some family members, especially towards people at low position, women and children. In that context, every family member must learn how to communicate through daily communication, whether verbal or non-verbal, selfimprovement to form a way of communication, behave in accordance with standards. Since then, the family fully performs their socialization functions, becoming the cradle to nurture, store and transfer traditional cultural values from generation to generation. It can be seen that, although the term "traditional Vietnamese family" is used according to a time convention, the reality still shows that 
the characteristics of the traditional Vietnamese family are still preserved in many modern Vietnamese families through values including respect for affection, living in love (Lê, 2015, para.15).

However, in the context of modern society some basic conditions of traditional society have been changed, leading to many other changes in communication, behavior and culture in the family. Traditional wet rice agriculture was gradually replaced by other economic activities, the influence of Confucian thought was increasingly narrowed down at the same time with the expansion of Buddhism's influence. Besides that, the trend of opening up integration, international exchange in culture was also focused. The profound influence of science and technology, particularly the penetration and influence of the Internet, are creating significant disturbances in the traditional communication culture of the Vietnamese family. In the context Vietnam ranks $6^{\text {th }}$ in Asia, $4^{\text {th }}$ out of $10^{\text {th }}$ in Southeast Asia and $17^{\text {th }}$ out of 20 countries with the most Internet users in the world (Trần, Trần, Nguyễn, Nguyễn, \& Trần, 2017), using the Internet too much affects the quality and effectiveness of communication in the family. In fact, there is a paradox that the more connected users on social media, the more lonely they feel (Turkle, 2017), that fact requires a comprehensive and comprehensive study on the influence of the Internet on communication in the Vietnamese family to help families to be more fully aware of this issue, thereby having solutions to use the Internet and communicate effectively, in accordance with national cultural traditions.

\section{References}

1. Alex, G. (1959). What is Communication. Journal of Communication, 9(5). Retrieved September 22, 2020 from https://onlinelibrary.wiley.com/doi/abs/10.1111/j.14602466.1970.tb00877.x

2. Ayer, A. J. (1955). What is communication? In Studies in Communication (pp. 11-28). London, England: Secker \& Warburg.

3. Andersen, P. A., \& Guerrero, L. K. (Eds.). (1997). Handbook of communication and emotion: Research, theory, applications, and contexts. California, United States of America: Academic Press.

4. Barnes, H. L., \& Olson, D. H. (1985). Parent-Adolescent Communication and the Circumplex Model. Child Development, 56(2), 438-447. JSTOR. https://doi.org/10.2307/1129732.

5. Barnlund, D. C. (1962). Toward a meaning-centered philosophy of communication. Journal of Communication, 12(4), 197-211. https://doi.org/10.1111/j.1460-2466.1962.tb01547.x

6. Beebe, S. A., Beebe, S. J., \& Redmond, M. V. (2000). Interpersonal communication. Scarborough, Canada: Prentice-Hall.

7. Bowlby, J. (1969). Attachment and Loss, Vol. 1: Attachment. New York, United States of America: Basic Books.

8. Bùi, M. Y. (1990). Xưng hô giữa vợ và chồng trong gia đình người Việt. [The vocation between husband and wife in Vietnamese family]. Tạp Chí Ngôn Ngũ , 3, 30-37.

9. Bùi, M. Y. (1993). Xưng hô giữa anh chị và em trong gia đình người Việt. [The vocation between older brothers/ older sisters and young brothers/ young sisters in Vietnamese family]. Tạp Chí Ngôn Ngũu, 3, 10-19.

10. Bùi, M. Y. (1994). Xưng hô giữa ông, bà và cháu trong gia đình người Việt. [The vocations between grandparents and grandchildren in Vietnamese family]. Tạp Chí Ngôn Ngũu, 2, 3140 .

11. Bùi, T. D. T. (2018). Sự thay đổi hình thức xưng hô trong giao tiếp gia đình Việt từ góc độ mạng quan hệ xã hội ngôn ngữ (khảo sát trên cứ liệu phim Hôn nhân trong ngõ hẹp). [The change in the form of vocation in Vietnamese family communication from the perspective 
of the social relationship network of language (survey on the data of Marriage in a narrow lane film]. Tạp Chí Khoa Hoc Đại Học Vinh, 47(2B), 37-45. Retrieved February 22, 2020 from http://www.vinhuni.edu.vn/DATA/0/Upload/618/DOCUMENTS/2018/11/2B2018/5\%20-2018-XH05

B\%C3\%B9i\%20Th\%E1\%BB\%8B\%20Di\%E1\%BB\%87u\%20Trang\%2037-45.pdf.

12. Carlson, L., \& Grossbart, S. (1988). Parental Style and Consumer Socialization of Children. Journal of Consumer Research, 15(1), 77-94. JSTOR. https://doi.org/10.1086/209147.

13. Cartier, F. A., \& Hanvood, K. A. (1953). On Definition of Communication. Journal of Communication, 3(2), 71-76. https://doi.org/10.1111/j.1460-2466.1953.tb01076.x.

14. Dance, F. E. X. (1970). The "Concept " of Communication. Journal of Communication, 20(2), 201-210. https://doi.org/10.1111/j.1460-2466.1970.tb00877.x.

15. Đào, T. M. N. (2014). Văn hóa gia đình Việt Nam: các giá trị truyền thống và hiện đại. [Vietnamese family culture: traditional and modern values]. Tạp chí Khoa học xã hộ Việt Nam, số 3(76). Retrieved February 24, 2020 from http://vci.vnu.edu.vn/upload/15022/pdf/576368227f8b9a1ec78b45ea.pdf.

16. DeVito, J. A. (2019). The interpersonal communication book (15th edition). New York, United States of America: Pearson Education, Inc.

17. Đỗ, T. Đ. (1990). Gia đình truyền thống và những biến thái ở Nam Bộ Việt Nam. [Traditional family and metamorphosis in the South of Vietnam]. Tạp Chí Xã Hội Học. $\begin{array}{llll}\text { Retrieved } \quad \text { February } & 2020 & \text { from }\end{array}$ file:///C:/Users/ACER/Downloads/So3_1990_DoThaiDong\%20(4).pdf.

18. Fiske, A. P. (2002). Using individualism and collectivism to compare cultures--A critique of the validity and measurement of the constructs: Comment on Oyserman et al. (2002). https://doi.org/10.1037/0033-2909.128.1.78.

19. Fitzpatrick, M. A., \& Ritchie, L. D. (1994). Communication Schemata Within the Family. Human Communication Research, 20(3), 275-301. https://doi.org/10.1111/j.14682958.1994.tb00324.x.

20. Forehand, R., Miller, K. S., Dutra, R., \& Chance, M. W. (1997). Role of parenting in adolescent deviant behavior: Replication across and within two ethnic groups. Journal of Consulting and Clinical Psychology, 65(6), 1036-1041. https://doi.org/10.1037/0022006X.65.6.1036.

21. Giddens, A. (2006). Sociology (5th Revised edition). Cambridge, UK: Polity Press.

22. Guerrero, L. K., Andersen, P. A., \& Afifi, W. A. (2007). Close Encounters: Communication in Relationships. California, United States of America: Sage Publications, Inc.

23. Hoben, J. B. (1954). English Communication at Colgate Re-Examined. Journal of Communication, 4(3), 76-83. https://doi.org/10.1111/j.1460-2466.1954.tb00232.x.

24. Huỳnh, C. B. (2012). Lịch sủ văn hóa Việt Nam (Tái bản có sủa chũa và bổ sung). [Vietnamese cultural history (Revised and supplemented edition)]. Huế, Việt Nam: Nhà xuất bản Thuận Hóa.

25. Khuất, T. L. (2014). Xưng hô trong giao tiếp vợ chồng nông dân người Việt (trên cứ liệu một số tác phẩm văn học giai đoạn 1930-1945). [Vocation in the communication between the farmer Vietnamese husband and wife (on the basis of some literary works from 19301945]. Tạp Chí Ngôn Ngũ và Đời Sống, 7, 18-25. Retrieved February 22, 2020 from https://tailieu.vn/doc/xung-ho-trong-giao-tiep-vo-chong-nong-dan-nguoi-viet-

2036650.html. 
26. Koesten, J., \& Anderson, K. (2004). Exploring the Influence of Family Communication Patterns, Cognitive Complexity, and Interpersonal Competence on Adolescent Risk Behaviors. Journal of Family Communication, 4(2), 99-121. https://doi.org/10.1207/s15327698jfc0402_2.

27. Lamont, M., \& Small, M. L. (2008). How Culture Matters: Enriching Our Understanding of Poverty. In A. C. Lin \& D. R. Harris. The colors of poverty: Why racial and ethnic disparities persist. New York, United States of America: Russell Sage Foundation.

28. Lê, T. B. H. (2015). Văn hóa ứng xử trong gia đình truyền thống và hiện đại. [Behavioral culture in traditional and modern families]. Hội Liên Hiệp Phụ Nữ Bắc Giang. Retrieved September 22, 2020 from https://hlhpn.bacgiang.gov.vn/ban-can-biet/van-hoa-ung-xutrong-gia-dinh-truyen-thong-va-hien-dai.htm.

29. Luhmann, N. (1992). What is Communication? Communication Theory, 2(3), 251-259. https://doi.org/10.1111/j.1468-2885.1992.tb00042.x.

30. McLeod, S. (2017). Attachment Theory. Simply Psychology. Retrieved February 5, 2017 from https://www.simplypsychology.org/attachment.html.

31. Miller, G. R. (1966). On Defining Communication: Another Stab. Journal of Communication, 16(2), 88-98. https://doi.org/10.1111/j.1460-2466.1966.tb00020.x.

32. Moore, R. L., \& Moschis, G. P. (1981). The Role of Family Communication in Consumer Learning. Journal of Communication, 31(4), 42-51. https://doi.org/10.1111/j.14602466.1981.tb00449.x.

33. Moschis, G. P., Prahasto, A. E., \& Mitchell, L. G. (1986). Family communication influences on the development of consumer behavior: Some additional findings. ACR North American $\begin{array}{lllll}\text { Advances. } & \text { Retrieved } & \text { February } & 5, & 2020\end{array}$ https://www.acrwebsite.org/volumes/6520/volumes/v13/NA-13.

34. Ngô Đ. T. (2006). Văn hoá, văn hoá tộc người và văn hoá Việt Nam. [Culture, ethnic culture and Vietnamese culture]. Hà Nội, Việt Nam: Nhà xuất bản Khoa học xã hội.

35. Nguyễn, H. M. (2015). Gia đình Việt Nam sau 30 năm đổi mới. [Vietnamese family after 30 years of renewal]. Tạp chí Khoa học xã hội Việt Nam, 11(96), 51-59. Retrieved February 5, 2020 from http://vci.vnu.edu.vn/upload/15022/pdf/5763695b7f8b9a31d08b4605.pdf.

36. Nguyễn, Q. T \& Cao, T. H. B. (2012). Quan hệ xã hội và vốn xã hội: Nghiên cứu so sánh Việt Nam và Hàn Quốc. [Social relations and social capital: Comparative study of Vietnam and Korea]. Tạp chí Xã hội học, số, 3, 119. Retrieved February 7, from So3_2012_NguyenQuyThanhCaoThiHaiBac.pdf.

37. Nguyễn, V. C. (1993). Từ xưng hô trong Tiếng Việt (nghiên cứu ngữ dụng học và dân tộc học giao tiếp). [Vocative words in Vietnamese (pragmatics and communicative ethnography]. VNU Journal of Science: Social Sciences and Humanities, 9(3), Article 3. Retrieved February 7, 2020 from https://js.vnu.edu.vn/SSH/article/view/4187.

38. Nguyễn, H. (2018). Giá trị văn hóa: Một số hàm ý cho nghiên cứu ngôn ngữ trên cơ sở giá trị văn hóa và giao tiếp liên văn hóa. [Cultural value: Some implications for linguistic research on the basis of cultural value and intercultural communication]. VNU Journal of Foreign Studies, 34(1), Article 1. https://doi.org/10.25073/2525-2445/vnufs.4221.

39. Ortner, S. B. (1984). Theory in Anthropology since the Sixties. Comparative Studies in Society and History, 26(1), 126-166. JSTOR. Retrieved February 6, 2020 from https://www.jstor.org/stable/178524?seq=1\#metadata_info_tab_contents.

40. Phạm, C. S. (2012). Văn hóa lễ tục $A B C$. [Rituals culture ABC]. Hà Nội, Việt Nam: Nhà xuất bản Văn hóa dân tộc. 
41. Punyanunt-Carter, N. M. (2008). Father-Daughter Relationships: Examining Family Communication Patterns and Interpersonal Communication Satisfaction. Communication Research Reports, 25(1), 23-33. https://doi.org/10.1080/08824090701831750.

42. Robinson, J. P., \& Levy, M. R. (1986). Interpersonal Communication and News Comprehension. The Public Opinion Quarterly, 50(2), 160-175. JSTOR. Retrieved February 10, 2020 from https://academic.oup.com/poq/article-abstract/50/2/160/1909519.

43. Schachter, S. (1951). Deviation, rejection, and communication. Journal of Abnormal Psychology, 46(2), 190-207. https://doi.org/10.1037/h0062326.

44. Schrodt, P., Ledbetter, A. M., Jernberg, K. A., Larson, L., Brown, N., \& Glonek, K. (2009). Family communication patterns as mediators of communication competence in the parentChild relationship. Journal of Social and Personal Relationships, 26(6-7), 853-874. https://doi.org/10.1177/0265407509345649.

45. Stevens, S. S. (1950). Introduction: A Definition of Communication. The Journal of the Acoustical Society of America, 22(6), 689-690. https://doi.org/10.1121/1.1906670.

46. Ting-Toomey, S., \& Dorjee, T. (2018). Communicating across cultures. New York, United States of America: Guilford Press.

47. Turkle, S. (2017). Alone together: Why we expect more from technology and less from each other. London, England: Hachette UK.

48. Trần, V. C., Trần, T. M. P., Nguyễn, T. T. H., Nguyễn, Q. C., \& Trần, N. T. A. (2017). Nhu cầu của học sinh trung hoc phổ thông về giáo dục an toàn mạng internet và một số giải pháp cho gia đình và nhà truòng. [High school students' needs for Internet safety education and some solutions for home and School]. Bài trình bày trong Kỷ yếu Hội thảo khoa học toàn quốc lần thứ 2 "Tâm lý học, giáo dục học với tình yêu, hôn nhân và gia đình". Hà Nội, Việt Nam: Nhà xuất bản Thông tin và truyền thông.

49. Trần, N. T. (2001). Co sở Văn hoá Việt Nam. [Basic of Vietnamese Culture]. Hà Nội, Việt Nam: Nhà xuất bản Giáo dục.

50. Trần, Q. V. (1996). Văn hóa học đại cuơng và cơ sở văn hóa Việt Nam: tài liệu dùng tham khảo giảng dạy và học tập trong các trưòng đại học. [General cultural studies and basic of Vietnamese culture: Materials used for teaching and learning in universities]. Hà Nội, Việt Nam: Nhà xuất bản Khoa học xã hội.

51. Trần, Q. V. (1997). Co sở văn hóa Việt Nam. [Basic of Vietnamese Culture]. Hà Nội, Việt Nam: Nhà xuất bản Đại học Quốc gia Hà nội.

52. Trần, Q. V. (1998). Việt Nam: cái nhìn địa văn hóa. [Vietnam: a geo-cultural look]. Hà Nội, Việt Nam: Nhà xuất bản Văn hóa dân tộc.

53. Trần, Q. V. (2016). Văn hóa Việt Nam: tìm tòi và suy ngẫm. [Vietnamese culture: research and ponder]. Hà Nội, Việt Nam: Nhà xuất bản Văn học.

54. Trần, D. T. (2005). Co sở văn hóa Việt Nam. [Basic of Vietnamese Culture]. Hà Nội, Việt Nam: Nhà xuất bản Văn hóa Thông tin.

55. Trenholm, A. J. S. (2008). Interpersonal communication (6th Edition). London, England: Oxford University Press.

56. Trương T. T. T \& Trần T. T. L. (2012). Cách ứng xử của trẻ vị thành niên đối với cha mẹ trong quá trình giao tiếp: phân tích từ một khảo sát thực địa [Adolescent behavior towards their parents during communication: analysis from a field survey]. Tạp chí Nghiên cúu gia đình và giới, (5), 77-87.

57. Vũ, D. (2008). Tù điển bách khoa. [Psychological Dictionary]. Hà Nội, Việt Nam: Nhà xuất bản Từ điển bách khoa, Viện Tâm lý học. 
58. ***Quốc hội Việt Nam [National Assembly Vietnam]. (2000). Luật Hôn nhân và Gia đình. [Law of marriage and family]. Mục 10, Điều 8. Chính trị Quốc gia, Việt Nam. Retrieved February 5, 2020 from https://thuvienphapluat.vn/van-ban/Quyen-dan-su/Luat-Hon-nhanva-Gia-dinh-2000-22-2000-QH10-46450.aspx. 